Document downloaded from:

http://hdl.handle.net/10251/59845

This paper must be cited as:

Peris-Ortiz, M.; Willoughby, MC.; Rueda Armengot, C. (2012). Performance in franchising: the effects of different management styles. Service Industries Journal. 32(16):2507-2525. doi:10.1080/02642069.2011.594876.

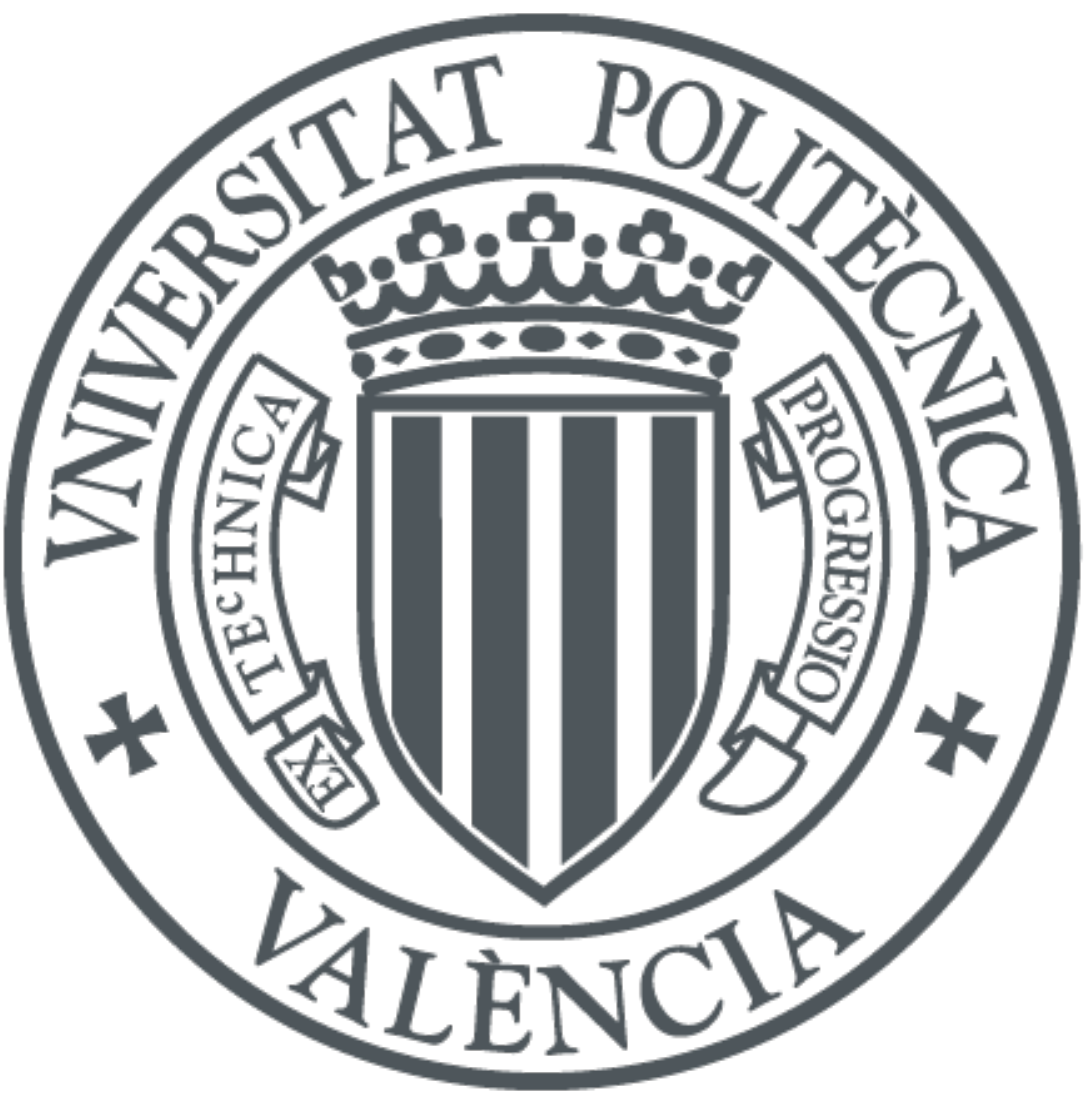

The final publication is available at

http://dx.doi.org/10.1080/02642069.2011.594876

Copyright Taylor \& Francis (Routledge): SSH Titles

Additional Information 


\title{
Performance in Franchising: the effects of different management styles ${ }^{1}$
}

\begin{abstract}
Various theoretical approaches uphold the relevance of the relationship between the form of management and performance. Different management styles influence relationships of agency (Jensen, 1998), the cost of governing transactions (Williamson, 1985) and the allocation of resources between the exploitation and exploration of activities (March, 1991), and this is manifested in firm performance. In light of these assumptions, this article presents an empirical verification of the relationship between the management of franchises and their performance, examining how different styles of management on the part of franchisers over their franchisees have significant effects on the growth and profits of franchiser firms.
\end{abstract}

KEYWORDS: franchises, styles of management, performance, franchiser-franchisee relations

\footnotetext{
${ }^{1}$ The authors are sincerely grateful for the efforts of the reviewers. Their suggestions have permitted a substantial improvement in the content of the article.
} 


\section{Introduction}

This article examines how different forms of management of franchises in Spain affect their performance. According to data from the Spanish Franchise Association (2009), in this country there are currently more than 900 registered brand names (approximately $80 \%$ of which are national), 70,000 establishments (owned either by the franchiser or the franchisee), with a total turnover of more than 25,000 million Euros.

In this study, the form or style of management, regarded as one of the fundamental explanatory variables in different organizational forms and their success or failure, is considered through various perspectives from organizational theory. Among other authors, Weick (1979), highlights that there is an ecological selection from the possible managerial proposals via the concept of enactment, and the best of these go to make up the business world; Child (1972), through the concept of strategic choice, has explicitly underlined in the contingent literature the importance (and the freedom) of managers to choose the way in which contingency factors are related; and Hambrick (Hambrick \& Mason, 1984; Hambrick, 2007) clearly considers that the characteristics of managers (experiences, values, and personality) and their interpretation of the firm's reality, constitute the fundamental explanatory variable of firm strategy and performance.

Along similar lines to the studies cited above and others related to franchises that examine the form of management and its relation to performance (Shane, 1996, 2001; Combs et al., 2006), this research examines the way in which franchisers in Spain combine forms of management or styles of direction that are analogous to the leadership types proposed by Liu et al (2003). These forms of management are similar to the directive, transactional, transformational or empowering leadership styles, or to a mixture of these forms.

The study is structured as follows: it begins with a review of some of the most relevant theoretical and empirical contributions in the literature on franchises. This review allows us to relate forms of management, agency issues and firm governance costs with performance; or to relate performance with the allocation of resources to the exploitation or exploration of new opportunities. The hypotheses of the study are then derived from this review. The following section describes the empirical study, in which 
we verify the extent to which the hypotheses can be confirmed via the corresponding regression equations.

Finally, the conclusions provide additional comment on the results obtained and show that the approach used in this research forms a part of a long tradition that recommends mixing the hard or formal parts of the contract (work contracts or cooperation agreements) with the softer parts, based on social relationships that increase understanding and trust.

\section{Theoretical framework and hypotheses}

We firstly address the literature on franchises, adding to this literature by providing a contribution on the use of resources in exploiting or exploring the activities and forms of management or leadership of the franchiser in terms of managing franchised outlets. We then go on to formulate the hypotheses of the study, based partly on the ideas contained in the theory reviewed herein.

The study of franchises has been approached from varying perspectives and with differing purposes, some of which adopt a theoretical approach that bears close relation to the object of the research and others where different perspectives focus on the same research topic. In this sense, the institutional approach (Combs, Michael \& Castrogiovanni, 2009), strategic literature that stresses the need for an adequate fit with resources (Gillis \& Combs, 2009) or with structure (Yin \& Zajac, 2004), the agency theory (Shane, 1996; Combs \& Ketchen, 1999), the resource-based approach (Mitsuhashi et al., 2008) or transaction cost economics (Combs \& Ketchen, 1999) constitute the main approaches that propose the explanatory variables of franchiser firms.

Other important research relates the survival and failure rate of franchises with institutional legitimacy or with the efficiency of the franchise contract (Shane \& Foo, 1999; Shane, 2001); or they explain the franchise within the framework of a strategy for attracting partners and increasing in size (Shane, Shankar \& Aravindakshan, 2006), avoiding a shortage of capital (Combs \& Ketchen, 1999), enabling adaptation to local tastes (Combs, Ketchen \& Ireland, 2006) or entry to other markets or countries (Combs \& Ketchen, 1999). 
In franchiser firms, franchising outlets imply a reduction in income on every item sold (compared to selling them in their own establishment), which will only be profitable if the franchising system allows them to sufficiently increase the number of items sold and/or reduce the proportion needed for the governance costs of the sales network. This is reliant on the existence of an efficient contract (Shane \& Foo, 1999; Shane, 2001). If the contract motivates efficient behaviour, a reduction in shirking can be expected from the employees at each outlet (Alchian \& Demsetz, 1972), along with cooperation between franchiser and franchisee in which free-riding or hold-up become less frequent (Klein et al., 1978).

Combs \& Castrogiovanni (1994), Combs \& Ketchen (1999) and Combs et al. (2006) highlight the advantages of the franchise system because of the greater strategic flexibility and controllability of this form of organization, which saves on recruiting, training and monitoring costs; and because of the advantages and opportunities for growth that derive from lesser strain on capital and other resources. Consistent with the agency theory (Jensen \& Meckling, 1976; Fama \& Jensen, 1983a, b), Shane (1996) suggests that by substituting managers on the payroll for owners of outlets, the problem of adverse selection is reduced, along with the subsequent one of moral hazard or opportunistic behavior, whilst enabling effective and efficient management.

However, while shirking in different outlets can be expected to fall off without additional costs for the franchiser, by transferring ownership of stores to franchisees, the possible problems posed by free-riding or hold-up cannot be solved as simply. The central idea to the agency theory (Jensen \& Meckling, 1995) that the problem will be solved by handing over ownership of the asset cannot fully occur in a franchise system, because the franchisee is "renting" the brand name of the franchiser and can indulge in free-riding in terms of product quality or customer care. By "renting out" the image and brand name, along with its procedures, the door is open to hold-up on the part of the franchiser by not investing sufficiently in advertising or by neglecting to make improvements in the design and content of the product.

As Williamson (1985: 26) points out, the solution to the problems mentioned above imply a total and ex ante alignment of incentives, a situation that normally exceeds the capacity of the agents involved (Simon, 1947), and thus the costs (and the incentives) ex post of an incomplete contract should be considered as an adaptation to the rational limitations of the agents involved. Such costs are fundamentally made up of supervisory 
costs associated with complying with an agreement and its adaptation to unforeseen circumstances (Williamson, 1985). This does not diminish efforts ex ante to establish a governance structure that correctly guides the behavior of the franchiser and the agents or owners of franchised outlets.

In this sense, the proposal for managing incentives derived from Williamson (1985: 135-141) is of particular interest. When applied to a franchiser firm, this proposal consists of passing on profits to independent units (outlets) as the alignment ex ante of the incentives of their owners (market incentives or high-powered incentives), completing the management of outlet owner behavior via the control ex post of those aspects of their business activity that are relevant to the franchiser firm (product quality or customer care and services). This control ex post, which relates to incentives that are internal to the common governance structure of the franchise, is similar to low-powered incentives Williamson suggests for the internal environment of organizations (less powerful incentives but which are essential for "completing" the system of incentives).

At this point, it should be noted that, in the alignment of incentives, there is a hard part, or "technical" part which could be called incentive design and a soft part, which is of a social nature and is based upon social acceptance and institutionalized norms and behavior (Orlikowski, 1992; Weick \& Roberts, 1993). It could be claimed that no system of incentives is complete without the soft part. Jensen (1998) referred to this issue when examining quality management systems. This author claims that the best process and job designs kindle love for the product amongst workers, which goes further than control systems in reducing agency problems.

We are also interested in discovering whether the franchiser, through the objectives and policies transmitted to franchisees, combines policies aimed at business exploitation with others aimed at the exploration of improvements in procedures and/or ways of attending and adapting to customer needs. In any firm, exploitation and exploration compete for the scarce resources and limited capabilities of the organization (March, 1991), although in the medium or long term, competitiveness means solving the dilemma in a balanced manner (Gupta \& Shalley, 2006; Sarkees \& Hulland, 2009), obtaining productivity from established routines whilst proposing new objectives and fostering learning (Winter, 2000, 2003).

In a first approximation, the franchiser is the one that will devote part of his/her investment to exploring new technical, organizational or market possibilities, with 
exploitation tasks predominating in franchised outlets. However, as suggested by Combs et al (2006), this is not always so. The franchisee may have greater knowledge of local tastes and of how to best interact with customers, a fact that may contribute to the success of the franchise and front end learning on the part of the franchiser.

If the franchise is efficient, there will be a satisfactory fit between the form of management adopted by the franchiser, the form of governance and the social, administrative and technical organization of the franchise (Altinay \& Okumus, 2010; Crook et al., 2010; Gillis \& Castrogiovanni, 2010; Hindle \& Moroz, 2010; Sánchez Gómez et al., 2010; Sánchez Gómez et al., 2011; Sebora \& Theerapatvong, 2010; Tihula \& Huovinen, 2010; Valliere, 2010; Vázquez, 2009; Wakkee et al., 2010). A satisfactory fit implies that, besides using technical tools for control (supervision of standard procedures in outlets), social control is enabled by basing it on institutionalized norms and behaviour. ${ }^{2}$ If this occurs, it will enable the control of problems related to behavior and incentive alignment that appear in the agency theory (AT) and in transaction cost economics (TCE), and could guide the actions of franchise members towards a suitable mixture of the exploitation of resources and the exploration of new possibilities, as can be drawn from the resource-based approach (RBV).

\section{Insert Table1}

Table 1 relates the possible forms of management of franchises to: 1) the effects on the form of governance (AT, TCE); 2) orientation towards the exploitation of resources and/or the exploration of new combinations of factors (RBV); 3) the alignment of incentives and behaviour (AT, TCE); 4) productive or commercial efficiency that is manifested in routines and capabilities (RBV); and 5) the forms or types of management and leadership (Liu et al., 2003) that correspond to each of the forms of management of franchises. The forms of management or leadership that we use in this article correspond to the classic forms of directive leadership, transactional leadership, transformational leadership and empowering leadership (Liu et al., 2003: 132).

Liu et al (2003) apply these concepts to internal aspects of the firm, as well as to certain characteristics of work, but we clearly give a different use to the forms of management or types of leadership and their applications to franchiser-franchisee relations in our article. We believe that the way in which we apply them to our research is suitable and

\footnotetext{
${ }^{2}$ The social institutionalization referred to here has notable precedents in the work of Barnard (1938), Gouldner (1961) and Ouchi (1980), and more recently in that of Jensen (1998).
} 
useful for constructing the article because (1) the different forms of management from TCE or from AT look to produce, in franchises, the same effects on workers as the types of leadership specified by Liu et al. (2003). (2) The different forms of management and leadership proposed by Liu et al (2003) are independent concepts from TCE or from AT and this enables their transversal use, covering essential aspects of both theories (enabling or hindering commitment and aligning incentives ex ante or ex post (table 1). (3) The use we make of the different forms of management and leadership allows us to relate these to the exploitation and consolidation of routines that are already established; or with exploration and the improvement of routines and capabilities (RBV). ${ }^{3}$

In light of the ideas expressed above, it can be expected that the forms of management that improve the problem of agency and reduce franchiser-franchisee costs (enabling the involvement of the latter or through the use of control mechanisms) will have a positive and significant relationship with the performance of the franchiser. The same may also be said of the forms of management that enable the exploitation or exploration of the activities, or a balance between them.

The form of management DS1 (rows 1, 2, 4, 14 and 15; table 1), in which shared objectives and trust are relevant elements that enable the initiatives of subordinates or partners to affect performance enabling, above all, the commitment to objectives and the alignment ex ante of incentives that will improve agency relations and transaction costs between franchiser and franchisee (see table 1). The mixture of items that make up the DS1 form of management, as a more advanced form, enables the allocation of resources to the exploration of new activities or opportunities without this impeding the balance of resource allocation towards exploration and exploitation. Hypothesis H1 formulates this idea.

Hypothesis 1 (H1): Forms of management based on transformational or empowering leadership (DS1, table 1) contribute to improving agency relations and transaction costs between franchiser and franchisee, and enable the allocation of resources to the exploration of activities, and have a positive, significant relation with the performance of the franchiser.

The DS2 form of management (table 1), in which, aside from control, the exchange of efforts and rewards between superior and subordinate or between partners is fundamental, will affect the performance of the franchiser through greater control over the franchisee (ex post alignment of incentives) and through clearer and unequivocal

\footnotetext{
${ }^{3}$ Although AT, TCE and RBV are frequently cited as alternative approaches in the study of different organizational phenomena, in terms of firm performance, they are, in fact, complementary.
} 
directives on the established routines that enable the allocation of resources to the exploitation of activities. This idea is expressed in hypothesis 2 .

Hypothesis 2 (H2): Forms of management based on directive or transactional leadership (DS2, table 1) contribute to improving agency relations and transaction costs between franchiser and franchisees and enable the exploitation of resources, and have a positive, significant relation with the performance of the franchiser.

Form of management DS3, in which the exchange of efforts and rewards between superior and subordinate or among partners, mixed with shared objectives and a convergence of interests is dominant, will affect performance, enabling commitment with objectives and ex ante alignment of incentives improving agency relations and transaction costs between franchiser and franchisee. The mix of items that make up the DS3 form of management enables the balance between exploitation and exploration of activities with somewhat greater emphasis on exploitation. This proposal is formulated in hypothesis 3.

Hypothesis 3 (H3): Forms of management based on transactional or transformational leadership (DS3, table 1) contribute to improving agency relations and transaction costs between franchiser and franchisees and, with greater emphasis on exploitation, enable a balance in resource allocation towards the exploitation or exploration of activities, and have a positive, significant relation with the performance of the franchiser.

The DS4 form of management (table 1), in which control over the subordinate or over the partner plays a fundamental role, will affect performance ensuring the strict compliance with norms, and will tend towards the allocation of resources to exploitation and a consolidation of established routines. This form of management, although it can reduce agency costs of the franchiser with regard to the franchisee, it is difficult to reduce transaction costs between the two. Relations based only on control, without other elements that orient behaviour to comply with objectives, increase the cost of governing the relationship or the transaction costs (Williamson, 1985).

Hypothesis 4 (H4): Forms of management based on a strict use of directive leadership (DS4, table 1), if the control is efficient, contribute to improving agency relations and will enable the allocation of resources of the franchisee to exploitation, and have a positive, significant relation with the performance of the franchiser.

The different managerial franchiser styles (table 1), and the results in terms of performance, should confirm the proposed hypotheses.

\section{Methodology and empirical results}

We go on to describe the design of the empirical investigation, the methodology used and the verification of the hypotheses. 
The reference population, 1026 franchises was taken from the quefranquicias web page in the year 2006, and questionnaires were sent to the managers of the franchiser firms, obtaining 103 replies, of which 7 were discarded due to bring incomplete. ${ }^{4}$ The maximum sample error for the 96 firms is thus $9.53 \%$, with a confidence level of $95 \%$ at worst (dichotomous questions in which $\mathrm{p}=\mathrm{q}=50 \%$ ). Questions on the form of management (or styles of leadership) of the franchiser were addressed to 192 franchised firms (small businesses), two for each franchiser firm, chosen from Spanish territory, which employed the most qualified managers. In this second case, both the reference population and the sample were duplicated, and thus the sample error is the same. Table 2 shows the sectors of activity of the franchiser firms and the percentages they present in the sample.

\section{Insert Table 2}

The $\mathrm{Chi}^{2}$ test (p-value 0.991 ) indicates that the proportion of firms by sector of activity is homogenous throughout the 12 sectors. All sectors have the same relative weighting for the analysis carried out.

The questions addressed to the managers of the franchiser firms, using 5-point Likert scales were as follows: performance of the firm, importance attributed to the environment for firm performance, the dynamic nature of the environment, and complexity of the environment. Secondly, the dichotomous questions posed were: do you own outlets in Spain?, do you charge royalties?, do you invest in advertising?, does the franchisee make an initial payment to the franchiser?, in which year did the firm begin franchising? (Regression models 1 and 2, tables 3 and 4).

The construct performance of the firm was obtained via questions on the levels of importance and levels of satisfaction of performance indicators and by then multiplying the values obtained for importance by the values obtained for satisfaction in each item. The items related to performance are growth in sales, return on investment (ROI), return on equity (ROE), return on sales (ROS), growth in market share and net profit (see Appendix).

Lastly, the questions posed to franchised outlets, via five-point Likert scales, appear in the left-hand column in table 1.

\footnotetext{
${ }^{4}$ The web page www.quefranquicia.com used for obtaining the population of franchises in this study is owned by the consultants Barbadillo Asociados (www.bya.com) and is the most complete franchise directory in Spain with access to over 1000 franchises.
} 


\section{Validity and reliability of the scales}

With regard to the validity of the scales, the scale that most needs to be founded on the literature is the scale that corresponds to the forms of management and leadership on the part of franchisers in their management of franchisees, which forms the basis of this study. The fundamental supposition in this research is that the different forms of franchise management will have repercussions on the behavior of franchisees and on performance (growth and profits) of the franchiser firm.

Rows 1-2, 4, and 14-15, in the first column of table 1 indicate a directive style (DS), in accordance with transformational or empowering leadership. Transformational leadership involves incentives that transcend self-interest in order to achieve a collective purpose (vision or mission) in the long-term, fostering trust and commitment (Liu et al., 2003: 133). When applied to franchises, this means that the form of management of the franchise has brought about feelings of love for the product or the service in franchisees (Jensen, 1998), thereby reducing the problems of agency. This makes the relationships between franchisers and franchisees correspond to what Williamson (1985) called fundamental transformation, in which relationships reach a specific value through mutual knowledge and the relationships of trust established, thus bringing down the governance costs of transactions.

Within this framework, one can expect more emphasis on the exploration of new possibilities, which are not contradictory to a possible balanced use of resources between exploitation or exploration. With respect to empowering leadership, which goes a step further by highlighting self-control and participation in building the firm in the long-term, it does not add any substantial variations to our research in terms of transformational leadership. In the left-hand margin, table 1 denotes the rows concerning transformational or empowering leadership with the label DS1 (directive style or leadership style 1).

Rows 7-9, in the first column of table 1, indicate a form of management that comes somewhere between directive and transactional leadership (DS2). Directive leadership acts on accommodating or submissive subordinates who accept the form of management, objectives assigned to the firm and the sanctions in place in the case of non-compliance. Transactional leadership is based on exchanges and agreements between the leader and 
his/her followers, and stresses an appropriate set of economic and social rewards that depend on attaining objectives. Control in complying with objectives and their link to the level of applying rewards and sanctions is the common characteristic of these two forms of leadership. This form of management entails greater emphasis on the exploitation of activities.

In the case of franchises, this means that the form of management of franchisees is based upon explicit incentives, control, and complying with clauses in the contract, and is thus closely related to the agency theory in terms of control (Fama \& Jensen, 1983a, b) and the explicit management (or design) of incentives (Jensen, 1998), along with transaction cost economics with regard to the formalization of contracts and their fulfilment (Williamson, 1993). This is another path towards the reduction of problems of agency and towards cutting down on the governance cost of transactions.

Rows 3, 5 and 10-12 of the first column in table 1 indicate a form of management that moves between transactional or transformational leadership (DS3). The allocation of resources to the exploitation of activities carries greater weight in this form of management, without hindering sufficient levels of balance in allocating resources to exploitation and exploration.

Finally, rows 6 and 13 of the first column of table 1 indicate a form of management that emphasizes the procedures and objectives assigned and the sanctions in the case of noncompliance, representing a strict use of directive leadership (DS4). This form of management can reduce the problems of agency if control is effective, but does not guide relationships that improve the overall transaction costs. The emphasis on procedures and objectives established entails the allocation of resources to exploitation.

With regard to the reliability of the scales, in order to analyze internal consistency, we used the Cronbach alpha statistic, whose optimum values are greater than or equal to 0.7 (Nunnally, 1978), although values greater than 0.6 are acceptable in research of an exploratory nature (Hair et al., 1999).

The Cronbach alpha values that correspond to the different constructs in the study are as follows: importance of the firm's performance objectives (0.658), satisfaction with the firm's performance (0.699), types of management or leadership on the part of the franchiser in managing franchises (0.709), importance of the environment (0.613), 
dynamic nature of the environment (0.672) and complexity of the environment (0.729). The remaining concepts researched correspond to dichotomous questions.

\section{Factor analysis}

Once the validity of the constructs in the most relevant case of forms of management has been established (table 1), and having verified the fulfilment of the conditions of reliability, we carry out a factor analysis for each construct. Grouping variables in this way allows us to deal with manageable relationships between the forms of management and firm performance, besides obtaining simpler expressions of the importance of the environment and its complexity.

With regard to firm performance, the factor analysis (Principal Component Analysis) groups the six variables into two factors: growth (in sales and market share) and financial results (ROI, ROE, ROS and net profit). In this factor analysis, the KMO (Kaiser-Meyer-Olkin) is 0.773 ; and the Bartlett sphericity test corresponds to the approximate chi-square 120,912, df 15, and Sig. 0.000 (regression models 1 and 2, tables 3 and 4).

In the forms of management or leadership of the franchiser, the factor analysis groups the variables into factors F1-F5 (Fi, left-hand margin, table 1) with certain discrepancies with regard to the forms or styles of management initially proposed (DSi, left-hand margin, table 1). However, this does not substantially modify the existence of a relevant, significant relationship between the form of management and the performance obtained, in accordance with the basic assumption of the article. The KMO here is 0.737 ; and the Bartlett sphericity test shows an approximate chi-square value of 645,851 , df 105 , and Sig. 0.000 .

The first discrepancy occurs in directive style 1 (DS1, table 1). The factor analysis introduces variable 11 into this form of management and removes variable 4 (factor F1, table 1), but this form of management clearly constitutes transformational leadership, in accordance with our initial proposal. Between DS2 and the variables grouped by factor 5 (F5, table 1), the coincidence is total; and in the same way, the DS4 proposed coincides with factor F4. The greatest discrepancy occurs in DS3. From the initial proposal on this form or style of management, plus variable 4 previously removed from DS1, the factor analysis forms two groups of variables: variables 4 and 5, which 
correspond to factor F3, and the variables 3, 10 and 12, which correspond to the new factor F2 (matrix of rotated components in Appendix, table 5).

Factor F3, which has a significant relationship with performance (regression model 2, table 4), maintains the directive style initially proposed (DS3), with a certain tendency towards empowering leadership (variable 4), which favours allocating resources to the exploration of opportunities, within the necessary equilibrium with exploitation, enabled by the training offered by the franchiser. Factor F2, despite being made up of similar items to those in F3, is not significant (regression model 2, table 4).

With regard to the control variables, the control variable importance of the environment is grouped into two components; importance 1 (competitive, consumer and technological environment) and importance 2 (economic and socio-cultural environment). Here, the regulatory environment variable has been removed to obtain a better KMO. We thus obtain a KMO of 0.649; and the Bartlett sphericity test shows an approximate chi-square of 44.692, df 10, and Sig. 0.000 .

The control variable dynamic nature of the environment has a single main component that groups changes into the competitive, consumer, technological, regulatory, economic and socio-cultural environment, with a KMO of 0.691; the Bartlett sphericity test shows an approximate chi-square of 76.659 , df 15 , and Sig. 0.000 .

The control variable complexity of the environment is grouped into two components; complexity 1 (technological, regulatory, economic and socio-cultural environment) and complexity 2 (competitive and consumer environment), with a KMO of 0.679; and the Bartlett sphericity test has an approximate chi-square 127.975, df 15, and Sig. 0.000.

The remaining control variables are dichotomous and are presented directly in regression models 1 and 2 (tables 3 and 4).

\section{Verification of the hypotheses and discussion of the results}

Regression models 1 and 2 are shown in tables 3 and 4 . The first of these relates the control variables with performance and the second incorporates the forms of management or leadership, thus forming the complete model.

$$
\text { Insert Table } 3
$$

Insert Table 4 
With regard to regression model 2, or the complete model, the regression equation obtained from the growth of the franchiser firm (growth in sales and/or market share) corresponds to management or leadership styles F1 and F3 (table 1), to the dynamic nature of the environment (DYN), royalties (ROY) and the upfront franchise fee (UFF):

GROWTH OF THE FRANCHISER FIRM $=0.321 * * *(\mathrm{~F} 1)+0.205^{* *}(\mathrm{~F} 3)+0.280 * *$ $(\mathrm{DYN})+0.461 * * *(\mathrm{ROY})-0.228 *(\mathrm{UFF})$.

The $\beta$ coefficient of DS1 in its F1 form $\left(0,321^{* * *}\right)$, which is positive and significant, confirms hypothesis 1 (H1). This form of managing franchisees through supporting their initiatives, improving management and treating them in a way that increases trust on both sides fosters commitment to the franchise, diminishes problems of agency and reduces the cost of governing transactions; all of which, together with the allocation of resources to exploration, is manifested in improved performance.

The $\beta$ coefficient of DS3 in its new F3 form $\left(0.205^{* *}\right)$, which is positive and significant, partially confirms hypothesis $3(\mathrm{H} 3)$. This form of management of franchisees provides stimuli and information so that outlets can explore new possibilities and better exploit activities. Regrouping items from DS3 to F3 adds empowering leadership to the mixture of transactional and transformational leadership, which reinforces the balance of the allocation of resources to exploitation and exploration, reducing the greater emphasis on exploitation.

In terms of the control variables, the $\beta$ coefficient of DYN $\left(0.280^{* *}\right)$, which is positive and significant, probably shows that the dynamic environment provides greater opportunities for the growth of the firm, although the focus of this study does not allow us to research this question.

The $\beta$ coefficient corresponding to $\operatorname{ROY}(0.461 * * *)$, which is positive, significant and strongly correlated to growth, appears to be an important control variable in explaining the growth of the franchiser. Charging royalties is an important source of income for financing all kinds of policies, among which is the exploration of opportunities.

Finally, the existence of UFF $\left(-0.228^{*}\right)$, which is negative and significant, indicates that the initial payment hinders growth due to the incorporation of new franchisees. ${ }^{5}$

\footnotetext{
${ }^{5}$ These last two results on control variables, however, proposed as hypotheses in the meta analysis of Combs and Ketchen (2003), are not corroborated in this analysis.
} 
Turning now to the regression equation obtained with regard to the different measures of financial performance of franchiser firms (ROI, ROE, ROS, net profit), this equation corresponds to the constant $0.361^{* * *}$, styles of management or leadership F1 and F5, importance 1 of the environment (IME1), the dynamic nature (DYN) and royalties (ROY):

INCOME-PROFITS OF THE FRANCHISER FIRM $=0.361 * * *+0.245^{* *}(\mathrm{~F} 1)+$ $+0.281 * * *(\mathrm{~F} 5)+0.189 *(\mathrm{IME} 1)+0.229 *(\mathrm{DYN})+0.284 *(\mathrm{ROY})$

The $\beta$ coefficient of DS1 in its F1 form $\left(0.245^{* *}\right)$, which is positive and significant, supports hypothesis $1(\mathrm{H} 1)$ for the same reasons put forward for the previous regression equation. This form of managing franchisees reduces problems of agency, cuts the cost of governing transactions and enables the allocation of resources to exploration, and is thus positively relate to performance.

The $\beta$ coefficient of F5 $(0.281 * * *)$, which is positive and significant (and incorporates the initial proposal of directive style DS2), confirms hypothesis $2(\mathrm{H} 2)$ for opposite and complementary reasons to those of directive style 1. This form of management, aside from the exchange of efforts and rewards, demands strict compliance with all procedures of production and commercialization, along with all actions that affect the image of the brand name, through inspections and formal control. Control dominates this form of governance aimed at consolidating existing routines and exploiting resources. If there is a correct exchange of efforts and rewards, and control is effective and efficient, this can all contribute to curtailing problems of agency and to reducing the governance costs associated with transactions.

The $\beta$ coefficient of IME1 $\left(0.189^{*}\right)$, which is positive and significant, indicates that the franchiser believes that he/she depends particularly on the competitive, consumer and technological environment.

The $\beta$ coefficient of DYN $\left(0.229^{*}\right)$, which is positive and significant, shows that the dynamic nature of the environment favours income and profits for the firm, just as it favours growth, as we saw in the previous regression equation. An examination of the correlations between different constructs (Appendix, table 6) shows a positive and significant (bilateral) correlation of 0.256 between DYN and F5, which may be interpreted in the sense that, as far as income and profits are concerned, franchiser firms 
face up to the dynamic nature of the environment by intensifying their own routines and ensuring the fulfilment of procedures that guarantee the efficiency of the exploitation of resources.

The $\beta$ coefficient of the ROY $\left(0.284^{*}\right)$, which is positive and significant, indicates, as expected, that royalties contribute to the income and profits of franchiser firms.

Finally, the constant $0.361 * * *$ indicates that there are elements or causes for the income and profit in franchises that are not explained by the regression model.

Style of Management DS4, which corresponds to factor F4, is not significant in any of the regression equations. Therefore, hypothesis $4(\mathrm{H} 4)$, which proposes a positive, significant relation between DS4 (strict control) and the franchising firm's performance is not confirmed.

\section{Conclusions}

The overall conclusion of this study is that the performance of franchiser firms (growth, income and profits) corresponds to the formulae:

(1) $\mathrm{GROWTH}=\beta 1(\mathrm{~F} 1)+\beta 2(\mathrm{~F} 3)+\beta 3(\mathrm{DYN})+\beta 4(\mathrm{ROY})-\beta 5(\mathrm{UFF})$.

(2) INCOME-PROFITS $=\alpha+\gamma 1(\mathrm{~F} 1)+\gamma 2(\mathrm{~F} 5)+\gamma 3(\mathrm{IME} 1)+\gamma 4(\mathrm{DYN})+\gamma 5(\mathrm{ROY})$.

Performance should not be expressed by just one formula, because growth and the different expressions of income and profit can move in opposite directions.

Observation of the equations (1) and (2) in regression model 2 shows that the form of management or leadership style 1 (DS1 in its F1 form) has a positive and significant coefficient both in terms of growth of the franchiser firm and with regard to profits. Management of franchisees characterized by fair treatment, support for initiatives and improvement in management conditions (see table 1) will increase trust between the two parties, encouraging commitment to the franchise, reducing problems of agency and cutting the governance costs of transactions, all of which, in addition to the allocation of resources to exploration, supports hypothesis 1 .

Secondly, the form of management or leadership style 3 (DS3 in its F3 form) has a positive and significant coefficient in the equation (1) that corresponds to growth of the franchiser. It is a form of management (table 1) that encourages the franchisee to 
address problems in a new way, proposing variations in the practices of the franchise (exploration), and facilities are given for improvement in their training and those of employees (exploitation). If this form of management enables a balanced use of resources between exploitation and exploration, in a framework that enables commitment between franchiser and franchisees, this favours the performance of the franchiser firm, as the regression coefficient indicates,. Hypothesis 3 (H3) is confirmed only partially, because of the change of items between DS1 and F1.

Thirdly, the form of management or style of leadership 5 (F5), which corresponds to the previous directive style DS2 (table 1), has a positive and significant coefficient for the equation (2) that corresponds to the income and profits of the franchiser. It is a form of management that emphasizes the demand for strict compliance of the procedures and actions that the franchisee must observe, establishing forms of inspection and control that, if they are effective, as the regression coefficient indicates, reduces problems of agency and cuts the governance costs associated with transactions. Moreover, this form of management consolidates established routines and guides resources towards exploitation, contributing to the fulfilment of hypothesis 2 .

Hypothesis $4(\mathrm{H} 4)$, which proposes a positive, significant relation between DS4 (strict control) and the franchising firm's performance is not confirmed. The DS4 form of management, which corresponds precisely to factor F4 (table 1), is not significant in either of the two regression equations.

In addition, observation of the control variables allows us to identify more stability in profits than in growth. In the equation (1) concerning growth in sales and/or market share, the relationships with the dynamic nature of the environment or with charging royalties are significant to a level of $95 \%$ and $99 \%$ respectively, while in the equation (2) that corresponds to income and profits, those same items are only significant to $90 \%$.

Finally, and on a more general note, this article attempts to contribute to research that relates the forms of management of franchises with performance. Scott Shane has addressed this question via the agency theory (1996) and the existence of efficient contracts (2001), and in the latter study highlights the fact that "many of the dimensions of efficient contracting on which firms are selected for survival are not hard contracting dimensions, but are dimensions of social control" (p. 136). 
This mix of hard or formal parts in the contract, which demand strict compliance of the stipulated agreements and procedures, and soft parts based on social relationships that increase understanding and trust between the parties, is the aspect we have attempted to explore with our approach to different forms of management or styles of leadership in table 1. We are thus applying a long tradition of schools of organizational thought on contracts to forms of governance. From the fields of sociology or economy, the search for a balance between the hard and soft parts of the contract have appeared in studies such as those of Barnard (1938), Gouldner (1961), Ouchi (1980) or Tsui et al (1997); and, although these authors refer fundamentally to internal contracts between the business owner and employees, this line of thought can be extended to any type of contractual relationship.

\section{Appendix.}

\section{Definitions:}

1. Return on Assets (ROA) or Return on Investment (ROI) tells an investor how much profit a company generates for each $\$ 1$ in assets. In this question, they were asked to provide information on the profit obtained in the last year before taxes.

$\mathrm{ROA}=$ Net Profit Margin $\mathrm{x}$ Asset Turnover

2. Return on Equity (ROE) measures the rate of return on the ownership interest (shareholders' equity) of the common stock owners.

ROE $=$ Net income after tax / Shareholder Equity

3. Operating Margin or Return on Sales is a measurement of what proportion of a company's revenue is left over, before taxes and other indirect costs and after paying for variable costs of production.

ROS = Operating Income / Net Operating Revenues

$$
\text { Insert Table } 5
$$

Insert Table 6

\section{REFERENCES}

Alchian, A.A., \& Demsetz, H. (1972). Production, information cost and economic organization, American Economic Review 62(5), 777-795. 
Altinay, L., \& Okumus, F. (2010). Franchise partner selection decision making. The Service Industries Journal 30(6), 929 - 946.

Barnard, C. (1938). The functions of the executive, Cambridge: Harvard University Press.

Child, J. (1972). Organization structure, environment and performance: The Role of strategic choice, Sociology 6, 1-22.

Combs, J G., \& Castrogiovanni, G. J. (1994). Franchisor strategy: A proposed model and empirical test of franchise versus company ownership, Journal of Small Business Management 32(2), 37-49.

Combs, J.G., \& Ketchen Jr., D.J. (1999). Can capital scarcity help agency theory explain franchising? Revisiting the capital scarcity hypothesis, Academy of Management Journal 42(2), 196-207.

Combs, J.G., \& Ketchen Jr., D.J. (2003). Why do firms use franchising us an entrepreneurial strategy? A meta-analysis, Journal of Management 29(3), 443-465.

Combs, J.G., Ketchen Jr., D.J., \& Ireland, R.D. (2006). Effectively managing service chain organizations, Organizational Dynamics 35(4), 357-371.

Combs, J.G., Michael, S.C., \& Castrogiovanni, G.J. (2009). Institutional influences on the choice of organizational form: The case of franchising, Journal of Management 35(5), 1268-1290. 
Crook, T.R., Shook, C.L., Madden, T.M., \& Morris, M.L. (2010). A review of current construct measurement in entrepreneurship, International Entrepreneurship and Management Journal 6(4), 387-398.

Fama, E.F., \& Jensen, M.C. (1983a). Agency problems and residual claims, Journal of Law and Economics 26, 327-349.

Fama, E.F., \& Jensen, M.C. (1983b). Separation of ownership and control, Journal of Law and Economics 26, 301-325.

Gillis, W.E., \& Combs, J.G. (2009). Franchisors strategy and firm performance: Making the most of strategic resource investment, Business Horizons 52(6), 553-561.

Gillis, W.E., \& Castrogiovanni, G.J. (2011). The franchising business model: An entrepreneurial growth alternative. International Entrepreneurship and Management Journal 7(1), in press.

Gouldner, A.W. (1961). The norm of reciprocity, American Sociological Review 25, 161-179.

Gupta, A.K., \& Shalley, C.E. (2006). The interplay between exploration and exploitation, Academy of Management Journal 49(4), 693-706.

Hair, J.F., Anderson, R.E., Tatham, R.L., \& Black, W.C. (1999). Análisis multivariante. Madrid: Prentice Hall.

Hambrick, D.C. (2007). Upper echelons theory: An update, Academy of Management Review 32(2), 334-343. 
Hambrick, D.C., \& Mason, P.A. (1984). Upper echelons: The organization as a reflection of its top managers, Academy of Management Review 9(2), 193-206.

Hindle, K., \& Moroz, P. (2010). Indigenous entrepreneurship as a research field: Developing a definitional framework from the emerging canon. International Entrepreneurship and Management Journal 6(4), 357-385.

Jensen, M.C. (1998). Foundations of Organizational Strategy. Cambridge: Harvard University Press.

Jensen, M.C., \& Meckling, W.H. (1976). Theory of the firm: Managerial behaviour, agency cost and ownership structure, Journal of Financial Economics 3, 305-360.

Jensen, M.C., \& Meckling, W.H. (1995). Specific and general knowledge and organizational structure, Journal of Applied Corporate Finance 8(2), 4-18.

Klein, B., Crawford, R., \& Alchian, A. (1978). Vertical integration, appropriable rents, and the competitive contracting process, Journal of Law and Economics 21(2), 297-326.

Liu, W., Lepak, D.P., Takeuchi, R., \& Sims Jr., H.P. (2003). Matching leadership styles with employment modes: Strategic human management perspective, Human Resource Management Review 13(1), 127-152.

March, J.G. (1991). Exploration and exploitation in organizational learning, Organization Science 2(1), 71-87. 
Mitsuhashi, H., Shane, S., \& Sine, W.D. (2008). Organization governance form in franchising: Efficient contracting or organizational momentum? Strategic Management Journal 29(10), 1127-1136.

Nunnally, J.C. (1978). Psychometric Theory, New York: McGraw-Hill.

Orlikowski, W.J. (1992). The duality of technology: Rethinking the concept of technology in organizations, Organization Science 3(3), 398-427.

Ouchi, W.G. (1980). Markets, bureaucracies, and clans, Administrative Science Quarterly 25, 120-142.

Sánchez Gómez, R., Suárez González, I., \& Vázquez, L. (2010). Multi-unit versus single-unit franchising: assessing why franchisors use different ownership strategies. The Service Industries Journal 30(3), 463-476.

Sánchez Gómez, R., Suárez González, I., \& Vázquez, L. (2011). Service quality control mechanisms in franchise networks. The Service Industries Journal 31(5), in press.

Sarkees, M., \& Hulland, J. (2009). Innovation and efficiency: It is possible to have it all, Business Horizons 52(1), 45-55.

Sebora, T.C., \& Theerapatvong, T. (2010). Corporate entrepreneurship: A test of external and internal influences on managers' idea generation, risk taking, and proactiveness. International Entrepreneurship and Management Journal 6(3), 331-350.

Shane, S.A. (1996). Hybrid organizational arrangements and their implications for firm growth and survival: A study of new franchisors, Academy of Management Journal $39(1), 216-234$. 
Shane, S.A. (2001). Organizational incentives and organizational mortality, Organization Science 12(2), 136-160.

Shane, S., \& Foo, M-D. (1999). New firms survival: institutional explanations for new franchisor mortality, Management Science 45(2), 142-159.

Shane, S., Shankar, V., \& Aravindakshan, A. (2006). The effects of new franchisor partnering strategies on franchise system size, Management Science 52(5), 773-787.

Simon H.A. (1947). Administrative Behavior: A Study of Decision-Making Processes in Administrative Organizations, New York: Free Press.

Tihula, S., \& Huovinen, J. (2010). Incidence of teams in the firms owned by serial, portfolio and first-time entrepreneurs. International Entrepreneurship and Management Journal 6(3), 249-260.

Tsui, A.S., Pearce, J.L.; Porter, L.W., \& Tripoli, A.M. (1997). Alternative approaches to the employee-organization relationship: Does investment in employees pay off? Academy of Management Journal 40, 1089-1121.

Valliere, D. (2010). Reconceptualizing entrepreneurial framework conditions. International Entrepreneurship and Management Journal 6(1), 97-112.

Vázquez, L. (2009). How passive ownership restrictions affect the rate of franchisee failure. The Service Industries Journal 29(6), 847-859.

Wakkee, I., Elfring, T., \& Monaghan, S. (2010). Creating entrepreneurial employees in traditional service sectors. The role of coaching and self-efficacy. International Entrepreneurship and Management Journal 6(1), 1-21. 
Weick, K.E. (1979). The social Psychology of Organization, Reading, Mass: Addison Wesley.

Weick, K.E., \& Roberts, K. (1993). Collective mind in organizations: Heedful interrelating on flight decks, Administrative Science Quarterly 38, 357-381.

Williamson, O.E. (1985). The economics institutions of capitalism: Firms, markets, relational contracting, New York: Free Press.

Williamson O.E. (1993). Calculativeness, Trust and Economic Organization, Journal of Law and Economics 36(1), 453-486.

Winter, S.G. (2000). The satisficing principle in capability learning, Strategic Management Journal 21, 981-996.

Winter, S.G. (2003). Understanding dynamic capabilities,. Strategic Management Journal 24(10), 991-995.

Yin, X., \& Zajac, E.J. (2004). The strategy/governance structure fit relationship: Theory and evidence in franchising arrangements, Strategic Management Journal 25(4), 365383. 
Table 1. Forms of management adopted by franchisers, basic theories and types of leadership

\begin{tabular}{|c|c|c|c|c|}
\hline & $\begin{array}{c}\text { Forms of } \\
\text { management in } \\
\text { franchises } \\
\text { (question posed to } \\
\text { franchised). }\end{array}$ & $\begin{array}{l}\text { Social effects/ } \\
\text { control in the form } \\
\text { of governance/org. }\end{array}$ & $\begin{array}{l}\text { Incentive } \\
\text { alignment/ } \\
\text { behavior, } \\
\text { routines, } \\
\text { capabilities }\end{array}$ & $\begin{array}{c}\text { Basic theories/ } \\
\text { types of } \\
\text { leadership }\end{array}$ \\
\hline $\begin{array}{l}1 \\
\text { DS1 }\end{array}$ & $\begin{array}{l}\text { The franchiser } \\
\text { clearly relays the } \\
\text { objectives of the } \\
\text { franchise with } \\
\text { regard to products } \\
\text { or services. }\end{array}$ & $\begin{array}{l}\text { Contributes to } \\
\text { governing the agency } \\
\text { relationship and } \\
\text { transactions. }\end{array}$ & $\begin{array}{l}\text { Alignment } e x \\
\text { ante of } \\
\text { incentives. } \\
\text { Enables } \\
\text { commitment to } \\
\text { objectives. }\end{array}$ & $\begin{array}{c}\text { AT, TCE. } \\
\text { Transformational } \\
\text { or Empowering } \\
\text { leadership. }\end{array}$ \\
\hline $\begin{array}{l}2 \\
\text { DS1 }\end{array}$ & $\begin{array}{l}\text { The franchiser } \\
\text { encourages } \\
\text { considering the } \\
\text { characteristics of the } \\
\text { environment as } \\
\text { opportunities, in the } \\
\text { framework of the } \\
\text { franchise business } \\
\text { practices. }\end{array}$ & $\begin{array}{l}\text { Improves the agency } \\
\text { rel. and transactions } \\
\text { Guides resources } \\
\text { towards exploration }\end{array}$ & $\begin{array}{c}\text { Enables } \\
\text { commitment, } \\
\text { incentives } e x \\
\text { ante. } \\
\text { Improves the } \\
\text { routines and } \\
\text { capabilities of } \\
\text { the franchise. }\end{array}$ & $\begin{array}{c}\text { AT, TCE, RBV. } \\
\text { Transformational } \\
\text { or Empowering } \\
\text { leadership. }\end{array}$ \\
\hline$(\mathrm{F} 2)$ & $\begin{array}{l}\text { The franchiser } \\
\text { makes me aware of } \\
\text { aspects in the } \\
\text { industrial sector that } \\
\text { I had not previously } \\
\text { considered. }\end{array}$ & $\begin{array}{l}\text { Improves the agency } \\
\text { rel. and transactions. } \\
\text { Exploitation/explora- } \\
\text { tion of resources. }\end{array}$ & $\begin{array}{c}\text { Enables } \\
\text { commitment, } \\
\text { incentives } e x \\
\text { ante. } \\
\text { Improves the } \\
\text { routines and } \\
\text { capabilities of } \\
\text { the franchise. }\end{array}$ & $\begin{array}{c}\text { AT, TCE, RBV. } \\
\text { Transactional or } \\
\text { Transformational } \\
\text { leadership. }\end{array}$ \\
\hline $\begin{array}{l}4 \\
\text { DS1 }\end{array}$ & $\begin{array}{c}\text { The franchiser } \\
\text { encourages me to }\end{array}$ & $\begin{array}{l}\text { Improves the agency } \\
\text { rel. and transactions. }\end{array}$ & $\begin{array}{c}\text { Enables } \\
\text { commitment, }\end{array}$ & $\begin{array}{l}\text { AT, TCE, RBV. } \\
\text { Transformational }\end{array}$ \\
\hline
\end{tabular}




\begin{tabular}{|c|c|c|c|c|}
\hline (F3) & $\begin{array}{l}\text { address problems in } \\
\text { a novel way by } \\
\text { proposing variations } \\
\text { on the practices of } \\
\text { the franchise. }\end{array}$ & $\begin{array}{l}\text { Guides resources } \\
\text { towards exploration. }\end{array}$ & $\begin{array}{l}\text { incentives ex } \\
\text { ante. } \\
\text { Improves the } \\
\text { routines and } \\
\text { capabilities of } \\
\text { the franchise. }\end{array}$ & $\begin{array}{l}\text { or Empowering } \\
\text { leadership. }\end{array}$ \\
\hline $\begin{array}{l}5 \\
\text { DS3 }\end{array}$ & $\begin{array}{l}\text { The franchiser } \\
\text { provides chances for } \\
\text { improving my } \\
\text { training and that of } \\
\text { my employees in } \\
\text { production or } \\
\text { customer care. }\end{array}$ & $\begin{array}{l}\text { Improves the agency } \\
\text { rel. and transactions. } \\
\text { Guides resources } \\
\text { towards exploitation. }\end{array}$ & $\begin{array}{c}\text { Enables } \\
\text { commitment, } \\
\text { incentives ex } \\
\text { ante. } \\
\text { Intensification } \\
\text { of established } \\
\text { routines. }\end{array}$ & $\begin{array}{l}\text { AT, TCE, RBV. } \\
\text { Transactional or } \\
\text { Transformational } \\
\text { leadership. }\end{array}$ \\
\hline $\begin{array}{l}6 \\
\text { DS4 }\end{array}$ & $\begin{array}{l}\text { The franchiser } \\
\text { makes me not trust } \\
\text { in receiving } \\
\text { leniency if there are } \\
\text { involuntary errors in } \\
\text { procedures. }\end{array}$ & $\begin{array}{l}\text { Improves the agency } \\
\text { relationship if } \\
\text { properly controlled. } \\
\text { Makes transactions } \\
\text { more expensive. }\end{array}$ & $\begin{array}{c}\text { Hinders } \\
\text { commitment, } \\
\text { incentives } e x \\
\text { ante. } \\
\text { Consolidation } \\
\text { of established } \\
\text { routines. }\end{array}$ & $\begin{array}{l}\text { AT, TCE. } \\
\text { Strict use of } \\
\text { Directive } \\
\text { leadership. }\end{array}$ \\
\hline $\begin{array}{l}7 \\
\mathrm{DS} 2\end{array}$ & $\begin{array}{l}\text { The franchiser } \\
\text { carries out } \\
\text { inspections and if } \\
\text { established practices } \\
\text { are not followed } \\
\text { may not renew } \\
\text { franchise contract. }\end{array}$ & $\begin{array}{l}\text { Control as a form of } \\
\text { governance. Guides } \\
\text { resources towards } \\
\text { exploitation. }\end{array}$ & $\begin{array}{l}\text { Alignment } e x \\
\text { post of } \\
\text { incentives. } \\
\text { Consolidation } \\
\text { of established } \\
\text { routines. }\end{array}$ & $\begin{array}{l}\text { AT, TCE, RBV. } \\
\text { Directive or } \\
\text { Transactional } \\
\text { leadership. }\end{array}$ \\
\hline $\begin{array}{l}8 \\
\text { DS2 }\end{array}$ & $\begin{array}{l}\text { The franchiser } \\
\text { demands strict } \\
\text { compliance of all } \\
\text { actions that } \\
\text { contribute to the } \\
\text { image of the brand }\end{array}$ & $\begin{array}{l}\text { Control as a form of } \\
\text { governance. Guides } \\
\text { resources towards } \\
\text { exploitation. }\end{array}$ & $\begin{array}{l}\text { Alignment } e x \\
\text { post of } \\
\text { incentives. } \\
\text { Consolidation } \\
\text { of established } \\
\text { routines. }\end{array}$ & $\begin{array}{l}\text { AT, TCE, RBV. } \\
\text { Directive or } \\
\text { Transactional } \\
\text { leadership. }\end{array}$ \\
\hline
\end{tabular}




\begin{tabular}{|c|c|c|c|c|}
\hline (F5) & name. & & & \\
\hline $\begin{array}{l}9 \\
\text { DS2 }\end{array}$ & $\begin{array}{l}\text { The franchiser } \\
\text { demands strict } \\
\text { compliance of all } \\
\text { procedures related } \\
\text { to the product or } \\
\text { service. }\end{array}$ & $\begin{array}{l}\text { Control as a form of } \\
\text { governance. Guides } \\
\text { resources towards } \\
\text { exploitation. }\end{array}$ & $\begin{array}{l}\text { Alignment } e x \\
\text { post of } \\
\text { incentives. } \\
\text { Consolidation } \\
\text { of established } \\
\text { routines. }\end{array}$ & $\begin{array}{c}\text { AT, TCE, RBV. } \\
\text { Directive or } \\
\text { Transactional } \\
\text { leadership. }\end{array}$ \\
\hline $\begin{array}{l}10 \\
\text { DS3 }\end{array}$ & $\begin{array}{l}\text { The franchiser } \\
\text { makes me rethink } \\
\text { my productive } \\
\text { activity in ways I } \\
\text { had not previously } \\
\text { considered. }\end{array}$ & $\begin{array}{l}\text { Improves the agency } \\
\text { rel. and transactions. } \\
\text { Exploitation/explora- } \\
\text { tion of resources. }\end{array}$ & $\begin{array}{l}\text { Enables } \\
\text { commitment, } \\
\text { incentives ex } \\
\text { ante. } \\
\text { Improves the } \\
\text { routines and } \\
\text { capabilities of } \\
\text { the franchise. }\end{array}$ & $\begin{array}{c}\text { AT, TCE, RBV. } \\
\text { Transactional or } \\
\text { Transformational } \\
\text { leadership. }\end{array}$ \\
\hline $\begin{array}{l}11 \\
\text { DS3 }\end{array}$ & $\begin{array}{l}\text { The franchiser } \\
\text { enables conditions } \\
\text { that allows for } \\
\text { appropriate } \\
\text { management of the } \\
\text { employees in } \\
\text { franchised outlets. }\end{array}$ & $\begin{array}{l}\text { Improves the agency } \\
\text { rel. and transactions. } \\
\text { Guides resources } \\
\text { towards exploitation. }\end{array}$ & $\begin{array}{l}\text { Enables } \\
\text { commitment, } \\
\text { incentives ex } \\
\text { ante. } \\
\text { Improves the } \\
\text { routines and } \\
\text { capabilities of } \\
\text { the franchise. }\end{array}$ & $\begin{array}{c}\text { AT, TCE, RBV. } \\
\text { Transactional or } \\
\text { Transformational } \\
\text { leadership. }\end{array}$ \\
\hline $\begin{array}{l}12 \\
\text { DS3 }\end{array}$ & $\begin{array}{c}\text { The franchiser } \\
\text { informs me on } \\
\text { aspects of my } \\
\text { commercial activity } \\
\text { or on my customers } \\
\text { that I had not } \\
\text { previously } \\
\text { considered. }\end{array}$ & $\begin{array}{l}\text { Improves the agency } \\
\text { and transactions rel. } \\
\text { Exploitation/explora- } \\
\text { tion of resources. }\end{array}$ & $\begin{array}{l}\text { Enables } \\
\text { commitment, } \\
\text { incentives ex } \\
\text { ante. } \\
\text { Improves the } \\
\text { routines of the } \\
\text { franchise. }\end{array}$ & $\begin{array}{c}\text { AT, TCE, RBV. } \\
\text { Transactional or } \\
\text { Transformational } \\
\text { leadership. }\end{array}$ \\
\hline $\begin{array}{l}13 \\
\text { DS4 }\end{array}$ & $\begin{array}{l}\text { The franchiser } \\
\text { makes me aware of }\end{array}$ & $\begin{array}{l}\text { Improves the agency } \\
\text { relationship if }\end{array}$ & $\begin{array}{l}\text { Hinders } \\
\text { commitment, }\end{array}$ & $\begin{array}{c}\text { AT, TCE. } \\
\text { Strict use of }\end{array}$ \\
\hline
\end{tabular}




\begin{tabular}{|c|c|c|c|c|}
\hline$(\mathrm{F} 4)$ & $\begin{array}{c}\text { how to avoid } \\
\text { possible sanctions. }\end{array}$ & $\begin{array}{c}\text { properly controlled. } \\
\text { Makes transactions } \\
\text { more expensive. }\end{array}$ & $\begin{array}{l}\text { incentives ex } \\
\text { ante. } \\
\text { Consolidation } \\
\text { of established } \\
\text { routines. }\end{array}$ & $\begin{array}{l}\text { Directive } \\
\text { leadership. }\end{array}$ \\
\hline $\begin{array}{l}14 \\
\text { DS1 }\end{array}$ & $\begin{array}{l}\text { The franchiser bears } \\
\text { in mind the needs } \\
\text { and interests of } \\
\text { franchisees. }\end{array}$ & $\begin{array}{l}\text { Contributes to } \\
\text { governing the agency } \\
\text { relationship and } \\
\text { transactions. }\end{array}$ & $\begin{array}{c}\text { Alignment } e x \\
\text { ante of } \\
\text { incentives. } \\
\text { Enables } \\
\text { commitment to } \\
\text { objectives. }\end{array}$ & $\begin{array}{c}\text { AT, TCE. } \\
\text { Transformational } \\
\text { or Empowering } \\
\text { leadership. }\end{array}$ \\
\hline $\begin{array}{l}15 \\
\text { DS1 }\end{array}$ & $\begin{array}{l}\text { The franchiser } \\
\text { congratulates } \\
\text { franchises with } \\
\text { excellent } \\
\text { performance. }\end{array}$ & $\begin{array}{l}\text { Contributes to } \\
\text { governing the agency } \\
\text { relationship and } \\
\text { transactions. }\end{array}$ & $\begin{array}{c}\text { Alignment } e x \\
\text { ante of } \\
\text { incentives. } \\
\text { Enables } \\
\text { commitment to } \\
\text { objectives. }\end{array}$ & $\begin{array}{c}\text { AT, TCE. } \\
\text { Transformational } \\
\text { or Empowering } \\
\text { leadership. }\end{array}$ \\
\hline
\end{tabular}

Abbreviations: rel. $=$ relationship; org. = organization. 
Table 2. Sector of activity of the surveyed firms

\begin{tabular}{|l|c|c|}
\hline Firms/sector & $\begin{array}{c}\text { Totals } \\
\mathbf{N}= \\
\mathbf{9 5}^{\mathbf{6}}\end{array}$ & $\begin{array}{c}\text { \% of the N in } \\
\text { the table }\end{array}$ \\
\hline Dietary products, drugstores, chemists, opticians, cosmetics & 9 & $9.47 \%$ \\
\hline Hotels and restaurants & 10 & $10.5 \%$ \\
\hline Commercialization and distribution of products or services & 10 & $10.5 \%$ \\
\hline Clothes, manufacturing, fashion and accessories & 8 & $8.4 \%$ \\
\hline Information technology, telecommunications & 9 & $9.47 \%$ \\
\hline Travel agencies, leisure & 8 & $8.4 \%$ \\
\hline Estate agents & 7 & $7.37 \%$ \\
\hline Food suppliers, Bakers, confectioners, ice cream parlors & 7 & $7.37 \%$ \\
\hline Construction, decoration, furniture, interior restoration & 8 & $8.4 \%$ \\
\hline Printing, stationers, office materials, sign making & 7 & $7.37 \%$ \\
\hline Automobile industry & 6 & $6.3 \%$ \\
\hline Others (centers of learning, cleaning services, etc.) & 6 & $6.3 \%$ \\
\hline
\end{tabular}

\footnotetext{
${ }^{6}$ Responses from a firm that does not identify its sector of activity are used here.
} 
Table 3. Regression model 1

\begin{tabular}{|l|l|l|}
\hline & $\begin{array}{c}\text { Growth } \\
(\boldsymbol{\beta})\end{array}$ & $\begin{array}{c}\text { Financial } \\
\text { performance ( } \boldsymbol{\beta})\end{array}$ \\
\hline Constant & 0.053 & $0.434^{* * * *}$ \\
\hline Importance of the environment 1 & 0.172 & 0.149 \\
\hline Importance of the environment 2 & -0.022 & $0.188^{*}$ \\
\hline Dynamic nature of the environment & $0.301^{* *}$ & $0.321^{* *}$ \\
\hline Complexity of the environment 1 & 0.033 & -0.059 \\
\hline Complexity of the environment 2 & -0.079 & -0.060 \\
\hline Franchiser: businesses in Spain? & -0.034 & -0.012 \\
\hline Does the franchiser charge royalties? & $0.347^{* * *}$ & 0.156 \\
\hline Does the franchiser invest in advertising? & 0.007 & 0.001 \\
\hline Franchisee: Is an initial payment made? & -0.119 & -0.057 \\
\hline Year in which the firm became franchise & 0.000 & -0.034 \\
\hline $\mathrm{R}^{2}$ & 0.242 & 0.208 \\
\hline Corrected R ${ }^{2}$ & 0.149 & 0.110 \\
\hline Durbin - Watson & 1.234 & 0.383 \\
\hline Snedecor F & 2.591 & 2.128 \\
\hline Significativity F & 0.009 & 0.031 \\
\hline
\end{tabular}

$* \mathrm{p}<.1 ; * * \mathrm{p}<.05 ; * * * \mathrm{p}<.01$ 
Table 4. Regression model 2

\begin{tabular}{|l|c|c|}
\hline & $\begin{array}{c}\text { Growth } \\
(\boldsymbol{\beta})\end{array}$ & $\begin{array}{c}\text { Financial } \\
\text { performance }(\boldsymbol{\beta})\end{array}$ \\
\hline Constant & -0.234 & $0.361^{* * *}$ \\
\hline Form of management or leadership 1 & $0.321^{* * *}$ & $0.245^{* *}$ \\
\hline Form of management or leadership 2 & -0.120 & -0.158 \\
\hline Form of management or leadership 3 & $0.205^{* *}$ & 0.161 \\
\hline Form of management or leadership 4 & 0.107 & -0.053 \\
\hline Form of management or leadership 5 & 0.162 & $0.281^{* *}$ \\
\hline Importance of the environment 1 & 0.175 & $0.189 *$ \\
\hline Importance of the environment 2 & -0.101 & 0.165 \\
\hline Dynamic nature of the environment & $0.280^{* *}$ & $0.22 *^{*}$ \\
\hline Complexity of the environment 1 & 0.104 & -0.031 \\
\hline Complexity of the environment 2 & -0.055 & -0.027 \\
\hline Franchiser: businesses in Spain? & 0.143 & 0.130 \\
\hline Does the franchiser charge royalties? & $0.461 * * *$ & $0.284 *$ \\
\hline Does the franchiser invest in advertising? & -0.082 & -0.111 \\
\hline Franchisee: Is an initial payment made? & $-0.228^{*}$ & -0.147 \\
\hline Year in which the firm became franchise & -0.051 & -0.052 \\
\hline R 2 & 0.400 & 0.347 \\
\hline Corrected R & 0.279 & 0.215 \\
\hline Durbin - Watson & 1.361 & 0.620 \\
\hline Snedecor F & 3.292 & 2.623 \\
\hline Importance of the environment 1 & 0.000 & 0.003 \\
\hline
\end{tabular}

$* \mathrm{p}<.1 ; * * \mathrm{p}<.05 ; * * * \mathrm{p}<.01$ 
Table 5. Matrix of rotated components of directive styles

$\begin{array}{llllllllll}\text { Encourages } & \text { consideration } & \text { of } & \text { the } & \mathbf{. 7 8 8} & .007 & -.007 & .225 & -.137\end{array}$ characteristics of the environment as opportunities within the framework of business practices.

\begin{tabular}{lllllll}
\hline Clearly communicates the objectives of & $\mathbf{. 7 2 3}$ & .262 & -.112 & -.056 & .136
\end{tabular} the franchise with regard to products and services.

\begin{tabular}{lllllll}
\hline Enables conditions that allow employees & $\mathbf{. 7 9 4}$ & .092 & -.009 & .124 & .001
\end{tabular}
of franchised outlets to be correctly managed.

\begin{tabular}{lllllllll}
\hline Congratulates & franchises that have & $\mathbf{. 6 5 8}$ & .103 & .170 & -.229 & .184
\end{tabular} excellent performance.

\begin{tabular}{llllll}
\hline Bears in mind the needs and interests of & $\mathbf{. 5 0 8}$ & .368 & .170 & -.016 & -.038
\end{tabular} the franchisees.

\begin{tabular}{lllllllll}
\hline Makes me rethink things about my & .265 & $\mathbf{. 7 3 0}$ & .023 & -.107 & .119
\end{tabular}
productive or commercial activity I had not previously considered.

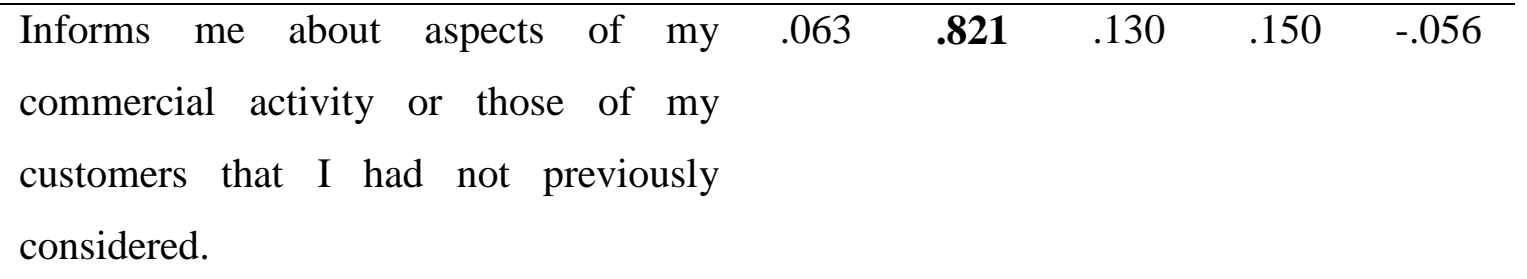
\begin{tabular}{llllll}
\hline Makes me aware of aspects concerning & .226 & .499 & .329 & .422 & -.213
\end{tabular} the industrial sector that I had not previously considered.

$\begin{array}{lllllllll}\text { Encourages me to address problems in a } & -.017 & .181 & \mathbf{. 8 1 0} & .068 & .035\end{array}$ new way, proposing variations in the practices of the franchise.

$\begin{array}{llllllll}\text { Enables me to improve my training and } & & .037 & .056 & \mathbf{. 7 4 9} & .248 & .071\end{array}$ that of my staff in production and customer care. 
$\begin{array}{llllllllll}\text { Makes me aware of how to avoid } & .007 & .017 & .240 & \mathbf{. 7 6 1} & .032\end{array}$ possible sanctions.

$\begin{array}{llllll}\text { Makes me not count on lenience if there } & .016 & .057 & .029 & \mathbf{. 7 4 6} & .239\end{array}$ are involuntary errors in procedures.

$\begin{array}{llllll}\text { Demands strict compliance of all actions } & -.382 & .007 & -.300 & .062 & \mathbf{. 5 9 7}\end{array}$ that contribute to the image of the brand name.

$\begin{array}{lllllll}\text { Carries out inspections and if established } & .075 & .007 & .069 & .257 & \mathbf{. 6 9 2}\end{array}$ procedures are not adhered to the franchise contract may not be renewed.

Demands strict compliance of all $\begin{array}{llll}.279 & -.030 & .341 & -.063\end{array}$ .596 procedures related to the product or service. 
Table 6. Correlations between constructs

\begin{tabular}{|l|lcccc|}
\hline & & Dynamism & STYLE 1 & STYLE 3 & STYLE 5 \\
\hline \multirow{4}{*}{ Dynamism } & Pearson correlation & 1 & -.164 & -.053 & $.256^{*}$ \\
\cline { 2 - 6 } & Sig. (bilateral) & & .116 & .614 & .013 \\
\cline { 2 - 6 } & $\mathrm{N}$ & 96 & 93 & 93 & 93 \\
\hline \multirow{5}{*}{ STYLE 1 } & Pearson correlation & -.164 & 1 & .000 & .000 \\
\cline { 2 - 6 } & Sig. (bilateral) & .116 & & 1.000 & 1.000 \\
\cline { 2 - 6 } & $\mathrm{N}$ & 93 & 188 & 188 & 188 \\
\hline \multirow{5}{*}{ STYLE 3 } & Pearson correlation & -.053 & .000 & 1 & .000 \\
\cline { 2 - 6 } & Sig. (bilateral) & .614 & 1.000 & & 1.000 \\
\cline { 2 - 6 } & N & 93 & 188 & 188 & 188 \\
\hline & Pearson correlation & $.256^{*}$ & .000 & .000 & 1 \\
\cline { 2 - 6 } & Sig. (bilateral) & .013 & 1.000 & 1.000 & \\
\cline { 2 - 6 } & N & 93 & 188 & 188 & 188 \\
\hline
\end{tabular}

*The correlation is significant at a level of 0.05 (bilateral) 